\title{
DUAS LEITURAS DA PAIXÃo
}

\section{TWO READINGS OF PASSION}

\author{
Arnaldo Cortina (UNESP) \\ (cortina@fclar.unesp.br)
}

Resumo: Este trabalho pretende apresentar a análise de dois textos tipologicamente distintos com o objetivo de discutir duas propostas de tratamento da paixão. Num dos textos ela será vista como elemento constituinte da narrativa e no outro como manifestação retórica da organização discursiva. A principal preocupação deste trabalho será, então, aplicar à análise de textos conceitos da semiótica de orientação greimasiana com vistas à reconstituição do processo interpretativo, tanto no âmbito interno quanto cultural do texto.

Palavras-chave: leitura; paixão; sentido; ponto de vista.

\begin{abstract}
This work intends to present an analysis of two typologically different texts, aiming to discuss two proposals of passion's handling. In one of the texts it will be regarded as a constitutive element of narrative and in the other as a rhetoric manifestation of the discourse's organization. Thus the main issue on this work will be to apply Greimassian Semiotics concepts to text analysis aiming to reconstitute the interpretive process of the text, both as regards its internal and its cultural scope.
\end{abstract}

Key-words: reading; passion; meaning; point of view. 


\section{Introdução.}

Ao inserirmos este texto nesta revista, temos como propósito inicial levar a cabo sua própria finalidade, qual seja, ser um CAderno de Semiótica Aplicada (CASA). Por esse motivo este trabalho não pretende apresentar nenhuma proposta teórica para o desenvolvimento da semiótica, mas sim fazer uma aplicação dos conceitos que transitam pelos estudos mais clássicos da semiótica greimasiana para produzir análise de textos. Não queremos com isso dizer que refletir teoricamente sobre a semiótica não seja uma tarefa importante. Pelo contrário, sem a discussão dos caminhos teóricometodológicos, a ciência não avança. Por outro lado, porém, muitas vezes é preciso fazer os conceitos funcionarem naquilo que é sua finalidade, isto é, a construção dos sentidos do discurso. Com esse intuito, portanto, não julgamos que seja preciso constantemente citar os diferentes textos teóricos da semiótica cada vez que nos reportarmos a determinados conceitos.

Assim propomos aqui realizar a análise de dois textos distintos, centrando nossa atenção na noção da paixão para a semiótica. Tomaremos esse conceito em duas dimensões distintas. Num primeiro momento verificaremos a paixão manifestada na narrativa e em outro a paixão enquanto componente retórico do discurso. Além disso, procuraremos observar como dois diferentes textos, escritos em épocas históricas distintas, constroem uma certa imagem do contexto cultural brasileiro. A maneira de abordagem dessa questão terá como estratégia a focalização do componente passional manifestado nos dois textos escolhidos para análise.

O primeiro texto selecionado chama-se "A desejada das gentes", escrito por Machado de Assis ${ }^{1}$. Esse conto aborda a temática amorosa, pois toda a ação narrada está centrada na exploração da problemática da paixão de um homem, o narrador, por uma bela mulher chamada Quintília. Ressalte-se que a proposta organizativa do conto não é o relato de um amor romântico, exaltado e entendido como bem sublime. Ao contrário, é um amor fruto de uma aposta entre dois homens que se vêem diante de uma mulher extremamente bela e rica. Examinaremos, portanto, como esse texto machadiano constrói a problemática da paixão por Quintília, instaurando-a no contexto de uma sociedade burguesa do final do século XIX, na cidade do Rio de Janeiro.

\footnotetext{
${ }^{1}$. Uma primeira referência ao caráter dialógico e ao passional desse conto de Machado de Assis já foi apresentada em CORTINA \& MARCHEZAN (2004).
} 
O segundo texto a ser examinado é uma crônica jornalística, intitulada "A ereção permanente" ${ }^{, 2}$ produzida pelo escritor peruano Mario Vargas Llosa, publicada, primeiramente, numa coluna do jornal espanhol El País, chamada "Piedra de Toque", depois reunida a várias outras que apareceram no mesmo jornal durante o espaço de tempo entre 1992 e 2000, e posteriormente publicadas num livro intitulado El lenguaje de la pasión, em fevereiro de 2001, pelas editoras El País e Aguilar, que foi traduzido para o português em 2002, com o título A linguagem da paixão, pela editora Arx. Utilizaremos neste trabalho a edição brasileira da crônica, mas sempre apresentaremos, em notas, o texto espanhol tal como foi publicado inicialmente no jornal.

Do ponto de vista tipológico, o texto de Vargas Llosa difere do de Machado de Assis, pois é dissertativo; do ponto de vista temático, apresenta as impressões de um sujeito enunciador sobre o carnaval brasileiro. O motivo pelo qual será analisado aqui neste trabalho consiste no fato de que a escrita de Vargas Llosa, sua forma de envolvimento com o tema e a defesa de seus argumentos se dá de forma apaixonada. Ao invés de narrar uma paixão, essa crônica é um exemplo de texto argumentativo que se constrói por meio de uma linguagem passional.

Além da questão da diferença do investimento passional nos dois textos, bem como da diferença tipológica, o que nos chama a atenção para o texto de Vargas Llosa é o fato de que ele reflete a leitura de um estrangeiro sobre uma manifestação cultural brasileira: o carnaval. Embora Vargas Llosa seja latino-americano, o que o torna um estrangeiro bastante próximo da realidade brasileira, é um homem que viveu muitos anos na Europa, em especial, Madri, Paris e Londres. Sua visão sobre o carnaval brasileiro, portanto, é marcada pela imagem que essa festividade tem no continente europeu, fruto das propagandas turísticas veiculadas nos países da Europa que pretendem atrair o público estrangeiro para o Brasil durante o período em que acontece o carnaval.

Os movimentos passionais na crônica jornalística de Vargas Llosa podem ser detectados na maneira como escreve sobre o carnaval brasileiro visto no Rio de Janeiro, apontando para o sentido eufórico da festa e do envolvimento do povo brasileiro nela presente. Sua escrita é passional ao mesmo tempo em que sua aproximação com o objeto de sua escrita também o é. Diferentemente do texto de Machado de Assis, o

${ }^{2}$. La erección permanente. 
tempo histórico em que se situa o tema do segundo texto é o presente, isto é, final do século XX.

No que concerne ao componente passional em semiótica, este texto tem como meta a discussão de dois diferentes aspectos. Em primeiro lugar, observará a manifestação da paixão na organização narrativa de um texto literário em que sujeitos e objetos estão relacionados por movimentos de atração e repulsão. Embora se possa admitir preliminarmente que o jogo passional do nível narrativo reflete-se no discursivo, nossa preocupação primeira será examinar a paixão como elemento significativo na relação entre actantes. Em segundo lugar, este texto procurará examinar a manifestação passional presente na organização discursiva de um texto não literário, na medida em que observará como o enunciador constrói para o enunciatário sua visão sobre o tema de seu discurso.

Ao mesmo tempo, porém, essa caracterização passional, quer no nível narrativo quer no discursivo, leva em consideração que o texto literário em exame é oriundo de um contexto histórico em que a razão está colocada em um patamar superior ao da emoção, o que é uma característica do movimento realista. No que se refere à literatura brasileira, esse é um modelo que a ela se incorpora por influência da literatura européia. Quanto ao texto não literário, a dimensão passional se manifesta num outro contexto histórico em que, poderíamos dizer, predomina uma visão pós-moderna do sujeito. Nesse contexto, a emoção sobrepõe-se à razão, na medida em que aponta para a noção de "liberdade", conceito central para o mundo contemporâneo. No que se refere à cultura brasileira do carnaval, o que Llosa procurará mostrar é que durante esse espetáculo concretiza-se na prática o exercício da liberdade, mesmo que condicionada no tempo e no espaço.

\section{A narrativa da paixão.}

O conto de Machado desenvolve-se na forma de um diálogo. Dois homens, o conselheiro (E2) 3 e seu amigo (E1), passam pela Glória, no Rio de Janeiro, e um deles, o conselheiro, lembra-se, por causa do lugar, de uma moça chamada Quintília. O

${ }^{3}$. Usaremos "E" para designar o Enunciador. Iniciamos a apresentação em ordem invertida, isto é, E2 aparecendo antes de E1, porque a primeira fala é do amigo do conselheiro, por isso E1, e a segunda é do conselheiro (o narrador), portanto, E2. 
propósito da lembrança está associado ao lugar e também a uma referência à lira, instrumento que evoca o amor. De início, E2 parece modalizado por um querer estar ao lado do objeto de seu amor, mas está dele separado por um fato irreversível: a morte. Assim, a colocação em cena da lembrança de Quintília é finalizada pelas seguintes frases: "Morreu em 1859. Vinte de abril. Nunca me há de esquecer esse dia." (p. 505). A partir desse momento E2 inicia um relato de um "caso trágico".

Esse relato, que se dá inteiramente por meio de diálogos, na medida em que só aparecem as falas trocadas pelo conselheiro e seu amigo, não é entremeado por nenhum discurso produzido por um sujeito narrador. Ele é um sujeito virtual, detectável apenas pela sucessão das falas, uma vez que elas não são aleatórias, mas fruto da escolha de um sujeito que é esse narrador tão amalgamado ao autor. Poderíamos dizer que esse tipo de narrador é o mesmo do teatro convencional; um sujeito da enunciação, mas um nãosujeito do enunciado. É essa a razão de sua estreita proximidade com a figura do autor.

A fala de E2, do conselheiro, constitui-se dialogicamente com a de E1, seu amigo de conversa, ao mesmo tempo que narra fatos acontecidos no passado. Nesse ato narrativo, outros sujeitos enunciam, por meio de um diálogo interno à fala de uma ou outra personagem. Segundo a noção de debreagem em semiótica, esse seria o caso de uma debreagem de segundo grau, pois E2 produz um discurso em que se manifestam projeções das falas de $e_{2}, e_{3}$, etc. Vejamos alguns exemplos:

(1) "Ao saber da minha briga com o amigo e companheiro da academia, e a separação em que ficamos, sentiu-se, não sei se diga, magoada ou irritada. Censurou-nos a ambos, não valia a pena que chegássemos a tal ponto.” (p. 509)

(2) “- A senhora diz isso, porque não sente a mesma cousa. - Mas então é um delírio? - Creio que sim; o que lhe afianço é que ainda agora, se fosse necessário, separar-me-ia dele uma e cem vezes; e creio poder afirmar-lhe que ele faria a mesma cousa.” (p. 509)

O diálogo reproduzido em (2) é exatamente a sequiência do que está reproduzido em (1). Assim, o sujeito enunciador em (1) é E2, o conselheiro, e os sujeitos enunciadores em (2) são, na ordem, $\mathrm{e}_{2} \mathrm{e} \mathrm{e}_{3}{ }^{4}$, sendo que o primeiro corresponde ao mesmo sujeito E2 anterior, ou seja, o conselheiro, e e 3 à Quintília. O conselheiro conta a

4. Usaremos a designação e 3 para indicar a debreagem de segundo grau da personagem Quintília para não confundirmos $e_{1}$ com uma possível debreagem de E1. Isso seria logicamente impossível na medida em que o amigo com quem o conselheiro conversa não pode participar da narração contada por E2, uma vez que os fatos se passam num tempo anterior do qual E1 estava ausente. 
seu amigo uma paixão que viveu alguns anos antes do encontro que deu origem a esse diálogo produzido entre os dois.

Antes propriamente do relato, além da referência à beleza de Quintília, tema que esteve presente na troca das falas iniciais entre E1 e E2, vem à tona a determinação da idade da morta. Tinha trinta anos quando o conselheiro a conheceu, em 1855, o que desperta a incredulidade em E1, pois ela lhe parecera muito mais moça, tendo em vista sua grande beleza. Para eliminar qualquer possibilidade de dúvida a respeito da idade de Quintília, E2 afirma que ela mesma havia revelado sua idade para ele, embora uma amiga, nascida no mesmo dia, afirmasse que ela tinha, na verdade, vinte e sete anos; ao que se segue o seguinte comentário: "dizia isso para diminuir-se a si própria" (p. 506). Em relação a essa observação de E2, E1 contrapõe a seguinte frase: "Mau, nada de ironias; olhe que a ironia não faz boa cama com a saudade.” (p. 506). Ao que E2 responde com a seguinte questão: "Que é a saudade senão uma ironia do tempo e da fortuna?" (p. 506).

Nesse jogo entre as palavras "ironia" e "saudade" há uma oposição entre algo que parece mas não é, a ironia, e aquilo que não se tem, mas que se gostaria de ter, a saudade. Enfim, uma contraposição entre uma conjunção falsa com um objeto e uma conjunção não realizada com outro. O relato que E2 inicia corrobora os conceitos de ironia e saudade, uma vez que sua história narra um fato irônico, isto é, que começou por um motivo e acabou numa situação totalmente contrária a sua proposta inicial; além disso, devido mesmo à ironia do destino, o conselheiro sentia saudades de Quintília, pois por ela havia se apaixonado no passado.

Tudo se inicia por uma brincadeira. O conselheiro vai ao teatro assistir "Os Puritanos" e escuta, nos corredores, comentários de alguns homens que exaltam a beleza de Quintília e seu caráter de fortaleza inexpugnável, que repelia todo pretendente a seu amor. Do ponto de vista da ação, essa conversa entre rapazes é que irá manipular o conselheiro a disputar o amor de Quintília. E o valor aventureiro desse contrato se dá na medida em que o conselheiro propõe a seu melhor amigo, Nóbrega, concorrerem juntos na tentativa da conquista, como numa aposta: ganharia quem se apossasse do coração de Quintília. Além da aventura que seria tentar seduzir uma mulher bonita que repelia todos os pretendentes, pois vencer sua tenacidade seria o reforço do valor sedutor masculino, somava-se, segundo conhecimento de Nóbrega, a conjunção com um outro objeto-valor representado na própria moça: a riqueza, uma vez que ela possuía muitos 
bens. Nesse ponto da narrativa pode-se observar que o desejo, modalizado pelo quererser, é responsável pelo desencadeamento de uma ação: conquistar para si o amor de Quintília.

Dentro do universo masculino, todos aqueles rapazes tinham seu apetite, a posse do sentimento e do corpo (porque não?) de Quintília, somado a sua riqueza, aguçado pela presença daquela mulher madura, mais velha que quase todos eles, e bela. $\mathrm{O}$ homem que fosse capaz de invadir aquela "fortaleza inexpugnável” (p. 506) teria não só o dinheiro e o prazer que Quintília poderia oferecer-lhe como também se sentiria superior aos outros homens que não teriam sido eleitos por ela para marido.

Valendo-se de um jogo entre contrários, expresso na frase "o homem põe e a espécie dispõe", o conselheiro conta para seu interlocutor que a empresa de conquista do coração de Quintília, que era um mero capricho, acabou destruindo a amizade entre ele e Nobrega, na medida em que um imprevisto atravessou o caminho dos dois: o despertar de uma paixão violenta pela bela mulher.

A frase enunciada por E1 em seguida ao relato da dissolução dos laços de amizade entre o conselheiro e seu colega de escritório, "Começo a ver uma pontinha do drama...” (p. 507), retrata o estado de tensão que o amor dos dois pela mesma mulher havia desencadeado. Em pouco tempo um já não falava mais com o outro a respeito de Quintília, logo depois já não mais se cumprimentavam. À frase de E1, E2 faz uma correção dizendo que não era um drama, mas uma tragédia: "Tragédia, diga tragédia" (p. 507). Mais um tempo decorrido e o conselheiro estava livre de Nóbrega na disputa pelo amor de Quintília, pois o colega de escritório havia conseguido "uma nomeação de juiz municipal lá para os sertões da Bahia, onde definhou e morreu antes de acabar o quatriênio." (p. 507). O afastamento e a morte do amigo provocam uma distensão na disputa. Nóbrega, mesmo com todo seu espírito prático e o apego ao fator monetário, sucumbe aos encantos de Quintília e, "ou por desengano verbal que ela lhe desse, ou por desespero de vencer" (p. 507), abandona o campo para seu rival.

Outros rivais apareceram para disputar a atenção de sua amada, mas nenhum obtinha sucesso, o que levava o conselheiro a alimentar uma esperança de que Quintília cederia somente a ele. $\mathrm{O}$ esperançoso é aquele que crê poder estar em conjunção com o objeto do desejo e assim é como se sentia E2. Suas esperanças cresciam na medida em que via que seu laço de união com Quintília não se dissolvia como o de outros pretendentes, ao que E1 comenta: "A razão é clara: achava a sua conversação menos 
insossa que a dos outros homens." (p. 508). Agora é o conselheiro que se mantém em estado de tensão. A espera, responsável pela manutenção do percurso da paixão complexa, como é o caso dessa instaurada no conto de Machado, passa a ser ajudada pela separação dos dois em função de um acontecimento: a doença do pai do conselheiro.

Com a ida de E2 a Itaboraí para acompanhar o estado de seu pai, fica instaurado um intervalo de tempo (quatro meses) que relaxa a tensão da espera. Por outro lado, o resultado desse tempo de afastamento entre o objeto do desejo e a possibilidade da posse corresponde a uma maior aproximação entre o conselheiro e Quintília. A volta para perto da amada, transcorrido aquele intervalo, cujo desfecho correspondeu à morte do pai, tem como resultado a retomada da espera, acrescida agora de um reforço da tensão que é própria a esse estado patêmico, uma vez que a compaixão de Quintília pelo estado de tristeza do conselheiro, em conseqüência do luto, pode ser um instrumento que a leve a ceder ao apelo da afeição que o conselheiro sente por ela. E a frase com que E2 demonstra isso é: "Quintília recebeu-me triste da minha tristeza, e vi claramente que o meu luto passara aos olhos dela..." (p. 508), ao que seu interlocutor acrescenta o seguinte comentário: "Mas que era isso, senão amor?" (p. 508).

A tensão da espera atinge seu grau mais agudo, a ponto de o próprio sujeito que narra seu estado dizer que estava iludido pelos índices que apontavam para a distensão, que corresponderia ao momento de aproximação entre os dois. Embora efetivamente Quintília não ceda aos apelos do conselheiro, aos olhos dos outros o compromisso já é praticamente certo. O sentimento de ilusão a que E2 se refere corresponde, ainda, à oposição parecer vs ser. Eles não estão unidos no nível do ser, embora estejam comprometidos no nível do parecer.

Outro incidente vem corroborar esse sentimento de proximidade entre ambos: a doença do tio de Quintília e sua morte em poucos dias. A retirada de cena desse tio poderia significar uma mudança no estado de espera, uma vez que algumas pessoas atribuíam ao fato de a moça não aceitar a proposta de nenhum pretendente o extremo apego do tio à sobrinha. A ausência do tio é preenchida pela chegada de uma prima viúva, D. Ana, que passa a morar com Quintília. O luto pelo tio soma-se ao luto do conselheiro pelo pai; à conjunção entre o sujeito apaixonado e o objeto de seu desejo no nível do parecer, soma-se uma identificação de estado: ambos estão de luto pela morte de um parente próximo e querido. Para que o estado da espera termine, levado, até 
então, à tensão absoluta, é preciso que o sujeito que o sofre realize um fazer: declarar-se abertamente àquela que é a razão do seu desejo. E o conselheiro escolhe o terraço perto da montanha, na casa do Cosme Velho, para fazer o pedido de casamento.

A resposta negativa de Quintília instaura a decepção, a paixão contrária à da esperança. Por outro lado ela não é uma resposta cabal, na medida em que é manifestada por um enunciado interrogativo-negativo seguido de um declarativo: "Casar para quê? Era melhor que ficássemos amigos como dantes.” (p. 509). Talvez por esse fato, instaura-se entre os dois uma seqüência argumentativa: ele para convencê-la a ceder; ela para fazê-lo aceitar a recusa. A resposta do conselheiro é a afirmação da recusa da simples amizade tendo em vista um sentimento mais forte que o impulsionava: "Respondi-lhe que a amizade era, em mim, desde muito, a simples sentinela do amor; não podendo mais contê-lo, deixou que ele saísse.” (p. 509). O contra-argumento apresentado por ela é o da idade, pois ele era mais novo que ela, embora sua gravidade lhe desse um ar de mais velho. Para rebater esse obstáculo, como último recurso, o conselheiro apela para a revelação de todos os fatos que o levaram a se aproximar dela, referindo-se então ao trato que havia feito com o colega Nóbrega no início. "Desesperançado, dei algumas passadas, depois sentei-me outra vez e narrei-lhe tudo." (p. 509).

O efeito desse argumento pela "sinceridade" tem quase um efeito inverso, pois Quintília acena com a possibilidade de se sentir ofendida quando fica sabendo que o conselheiro havia se aproximado dela para disputar com Nóbrega a mão de uma mulher bonita e rica. Essa situação colocou-a na real condição de um objeto de disputa, e isso parecia um ato de uma leviandade para a qual o interlocutor do conselheiro já havia apontado no início da narração dos fatos. Mas Quintília não se ofende; ao contrário, mantém o conselheiro preso pelo perdão, o que se torna um argumento indiscutível para a manutenção da recusa, pois era a prova de que ela tinha uma afeição muito forte pelo pretendente, embora não fosse amor. "Fiquemos amigos, disse-me, estendendo a mão." (p. 509).

Um novo afastamento entre ambos, causado pela partida do conselheiro para Itaboraí onde precisava resolver alguns problemas do inventário do pai, distenderá o sentimento de frustração instaurado pela recusa. Quando volta, depois de três semanas, o conselheiro encontra uma carta de Quintília solicitando que ele vá vê-la. A carta é redigida num tom meigo e grave, em que é questionado o desaparecimento do 
conselheiro, e seguida por uma promessa que reafirmava a proposta de amizade entre os dois, ao mesmo tempo em que mantinha acesa a esperança: "Quer uma garantia? Jurolhe que não casarei nunca." (p. 510).

$\mathrm{O}$ argumento que o conselheiro apresenta para não aceitar a proposta de Quintília é o sentimento daquele que tem vergonha da submissão ao fazer do outro: a humilhação. Depois de toda a espera, depois de todas as tentativas, aceitar uma recusa final era colocar-se numa posição de quem é humilhado pelo outro. Mas contra essa declaração, Quintília apresenta um argumento lógico: "não fale de humilhação, onde não houve público" (p. 510). A frase dita por ela mantém a oposição ser vs parecer, na medida em que não desfaz os comentários dos outros sobre o fato de os dois estarem envolvidos, uma vez que a impossibilidade do casamento entre ambos é sabida apenas por eles, numa situação de intimidade. Essa frase reforça ainda o sentido do emprego, utilizado pelo enunciador, do nome "humilhação". Esta só acontece na medida em que a submissão de um sujeito ao fazer do outro é testemunhada por um terceiro, o observador, o que não havia acontecido no caso da recusa de Quintília ao pedido do conselheiro. Novamente se restabelece a esperança, caracterizada pelo reavivamento da tensão da espera: "Não se falou em nada; ao princípio, custou-me muito parecer o que era dantes; depois, o demônio da esperança veio pousar outra vez no meu coração; e, sem nada exprimir, cuidei que um dia, um dia tarde, ela viesse a casar comigo." (p. $510)$.

Essa segunda espera instaurada por E2 é aquela própria do amante já desenganado, que sabe ter remotas chances de possuir o objeto amado. Não se pode, porém dizer que a espera está em situação de relaxamento, porque se assim estivesse não existiria; a espera tem sempre que conter uma tensão, ser, portanto, eufórica. O que diferencia a primeira espera da segunda é apenas a diminuição do grau de intensidade. Enquanto vive a segunda espera, E2 observa atentamente o objeto do desejo para poder avaliar as reais possibilidades de sua obtenção. Sua constatação é a de que Quintília não se apaixonava, desconhecia esse sentimento: "Foi então que a estudei muito; escutando as suas leituras vi que os livros puramente amorosos achava-os incompreensíveis, e, se as paixões aí eram violentas, largava-os com tédio. Não falava assim por ignorante; tinha notícia vaga das paixões, e assistira a algumas alheias.” (p. 511). Ela era uma mulher que não se envolvia, por exemplo, com a leitura amorosa, o que a diferenciava da mulher da segunda metade do século XIX, que era a leitora das histórias de amor. 
Eis que subitamente a espera é satisfeita e Quintília, finalmente, casa-se com o conselheiro. Mas em que situação? No leito de morte, quando já havia sido desenganada pelo médico, acometida de uma doença incurável. O que acontece, nesse ponto da narrativa, é a mudança de estado do narrador. Ele passa de um sujeito da espera para um sujeito da falta; o casamento acontece, a posse dos bens de Quintília também, mas o corpo dela não. O fazer de Quintília (casar-se com seu pretendente) é uma recompensa ou uma punição? Ela é um destinador-julgador ambíguo; ocupa a função própria de quem julga, mas não deixa claro como está julgando. Seu último ato antes da morte foi impulsionado pela piedade? Quintília sentia culpa por não poder corresponder ao amor do conselheiro? O interlocutor do conselheiro, em sua última fala no conto, expressa sua incompreensão em relação ao fazer da moça. Sua frase é: "tudo isso é bem esquisito" (p.511).

O último enunciado que corresponde à fala do conselheiro, com a qual encerrase o conto, será, de certa forma, uma tentativa de explicação para o fato de Quintília ser uma "fortaleza inexpugnável", a maneira como os diversos rapazes que se interessaram por ela caracterizavam-na, no início do conto, e que deu o mote à disputa estabelecida entre o conselheiro e seu amigo Nóbrega: "Não sei o que dirá a sua fisiologia. A minha, que é de profano, crê que aquela moça tinha ao casamento uma aversão puramente física. Casou meio defunta, às portas do nada. Chame-lhe monstro, se quer, mas acrescente divino." (p. 511). O fato de dizer que "aquela moça tinha ao casamento uma aversão puramente física" significa dizer que ela não sentia desejo físico por nenhum homem? Por esse motivo ela era uma pessoa que não se apaixonava? As ambigüidades narrativas são em Machado uma forma de captar o leitor.

Do ponto de vista do sentido da paixão como "afeto dominador e cego; obsessão", conforme a define Ferreira (1999, p. 1474), não há nenhuma manifestação nas falas de E2 que caracterizem Quintília como um sujeito apaixonado. Do ponto de vista da paixão enquanto "effet [en discours] de deux déterminations: d'un côté des déterminations modales, et de l'autre les déterminations tensives" (Fontanille, 1998, p. 200), podemos dizer que ela é um sujeito apaixonado.

Já pudemos observar no início desta análise que o texto de Machado de Assis constrói-se na forma de um diálogo mantido entre dois interlocutores: um amigo indeterminado (E1) e o conselheiro (E2). Durante esse diálogo um fato é narrado: a

5 . "efeito [no discurso] de duas determinações: por um lado, das determinações modais, e por outro, das determinações tensivas" (tradução nossa). 
paixão do conselheiro por Quintília. Ao narrar os fatos, E2 atravessa, portanto, todos os enunciados atribuídos a Quintília. Não é por esse motivo que devemos dizer que não é possível analisar seu discurso pelo viés das paixões, pois o que demonstramos em nossa análise foram exatamente os investimentos modais e tensivos por meio dos quais é construído o discurso da narração, incluindo-se aí o dos sujeitos que movimentam a narrativa. Da mesma forma, é possível tomar o ponto de vista das paixões manifestas no discurso para analisar os sujeitos em diálogo que constroem o texto machadiano, ou seja, explicitar as determinações modais e tensivas que organizam seus discursos. Além disso, na medida em que, como também já foi dito no início da análise, o texto de Machado de Assis constrói-se por meio da organização discursiva que a ele lhe dá o sujeito da enunciação, é possível dizer que esse sujeito da enunciação é manifestado na forma de um narrador que não fala, que não enuncia, portanto um "narrador ausente". Mas ausente enquanto manifestação, não como forma.

Se compararmos N1, que corresponde ao narrador ausente acima referido, e N2, narrador dos acontecimentos que envolveram Quintília e ele próprio, podemos dizer que há diferença de gradação na maneira de eles se construírem como sujeitos apaixonados. N1 procura ser mais neutro, o que o aproxima da noção de observador ${ }^{6}$. Como um camera-man que registra um diálogo entre duas pessoas, ele não enuncia uma palavra que lhe possa ser diretamente atribuída, mas o foco e a imagem que cria para cada um dos sujeitos em comunicação denunciam sua presença. Enfim, o espectador/leitor vê/lê aquilo que o olhar do narrador/camera-man registra. Mais sutil que o filme, porque não tem o recurso da imagem visual, N1 manifesta-se enquanto sujeito de discurso no momento em que escolhe o enunciado que será a fala das personagens em diálogo no conto.

N2, por sua vez, é o sujeito completamente envolvido com a narrativa; ele conta os fatos e deles participa. Desse ponto de vista, é diametralmente oposto a N1, porque manifesta um alto grau de parcialidade: tudo é contado a partir de seu ponto de vista. Mesmo quando reproduz uma fala de Quintília seu fazer como narrador é idêntico ao de N1, pois ele escolhe o que fazer a moça dizer. Essa debreagem de segundo grau envolve um processo complexo de projeção enunciativa na medida em que a fala de Quintília é atravessada pelo discurso do N2, ao mesmo tempo que seu discurso é atravessado pelo do N1, o que significa reconhecer um reflexo de N1 sobre a fala da heroína da narrativa.

6 Uma discussão sobre a noção do observador para a semiótica pode ser encontrada em Fontanille (1989). 
E é exatamente essa marca de subjetividade de $\mathrm{N} 2$ que mantém a ambigüidade do comportamento de Quintília, como pretendemos mostrar acima. O conselheiro constrói para o leitor sua imagem da mulher desejada ${ }^{7}$, de forma bastante semelhante à maneira como foi construída, no romance Dom casmurro, a imagem de Capitu, pelo narrador Bentinho.

Se pensarmos nesse momento o conto em análise como se dirigindo a um leitor, podemos dizer que o enunciatário construído no texto corresponde à figura do leitor como um espectador oculto que presencia a troca de diálogo como se estivesse por detrás de um vidro e que não pode ser visto pelos sujeitos que estão do outro lado.

Mas o leitor deste texto poderia dizer que um estudo das paixões enquanto procedimento de organização de um discurso é mais simples de ser realizado quando o texto de análise é uma narrativa literária que tem como tema central exatamente a questão da paixão. Vamos tentar mostrar aqui que um texto argumentativo também pode ser analisado do ponto de vista das manifestações passionais. Ao abordarmos a questão das paixões nesse tipo de texto argumentativo, temos que levar em consideração os processos e mecanismos modais e tensivos presentes na sua constituição retórica.

\section{A paixão no discurso argumentativo.}

O discurso do texto de Vargas Llosa constitui-se, no que se refere à categoria da pessoalidade, a partir de um procedimento de debreagem enunciativa, em que o sujeito da enunciação projeta no enunciado uma primeira pessoa. Lingüisticamente isso pode ser observado por meio da utilização dos pronomes de primeira pessoa toda vez que o sujeito enunciador faz referência a si próprio. No último parágrafo do texto, o enunciador se constitui por um procedimento de embreagem a partir do qual a referência a si mesmo se dá por meio do uso da terceira pessoa. Nessa passagem, a instância da enunciação se manifesta da seguinte maneira: “(...) a representação nele [no inferno] de brasileiras será seguramente maior que o de todas as outras sociedades juntas (o que não deixa de ser um alívio para os pecadores não redimidos como este

7 . "Lembra-se bem que era magra e alta; tinha os olhos, como eu então dizia, que pareciam cortados da capa da última noite, mas apesar de noturnos, sem mistérios nem abismos. A voz era brandíssima, um tanto apaulistada, a boca larga, e os dentes, quando ela simplesmente falava, davam-lhe à boca um ar de riso. Ria também, e foram os risos dela, de parceria com os olhos, que me doeram muito durante certo tempo." (p. 506) 
escriba) $)^{8} . "$ (p. 287 - grifo nosso). O sintagma “este escriba”, embora possa refletir uma forma de apagamento da marca de pessoalidade, é uma referência ao sujeito enunciador que recupera, inclusive, sua ação: escrever. Dessa forma, o enunciador chama a atenção do leitor para o meio através do qual eles se comunicam, isto é, por via do texto escrito. Nesse contexto ainda, poderíamos dizer que fica evidenciada sua condição de escritor.

Do ponto de vista das projeções temporais e espaciais, o discurso do texto de Llosa instaura um "agora" e um "aqui", pois esse sujeito manifestado pelas formas da primeira pessoa quer localizar seu ato de enunciação no momento presente (os dias das festividades do carnaval de 1999) e na cidade do Rio de Janeiro. O tempo verbal do discurso de relato daquilo que o enunciador presenciou durante o período do carnaval é o pretérito, enquanto as análises e considerações do enunciador com relação a essas festividades e à conjuntura social e política brasileira são manifestadas pelo tempo verbal presente. A dimensão temporal da experiência do enunciador com o carnaval brasileiro é concretizada no espaço de tempo relativo a uma semana, como demonstra o seguinte trecho de seu discurso: "Tudo o que vi e ouvi nessa fulgurante semana carioca parece uma ilustração animada (...)."9 (p. 285 - grifo nosso). Dessa forma, o efeito de sentido que isso causa é o de que o discurso se produz proximamente ao período em que o enunciador viu e viveu as festividades do carnaval carioca. Um outro recurso, recorrente em todas as crônicas do livro de Llosa, é o aparecimento de uma data que localiza temporal e espacialmente o enunciado. No caso do texto que analisamos, a datação se manifesta da seguinte forma: "Rio de Janeiro, fevereiro de 1999".

Além de criar o efeito de sentido de subjetividade próprio dos discursos construídos pela debreagem enunciativa, este procedimento discursivo desencadeia dois outros efeitos textuais. Por um lado, determina a linguagem própria da crônica jornalística que é diferente da reportagem jornalística, por exemplo. Embora esse tipo de texto tenha também o interesse de informar o leitor sobre um acontecimento, dá margem a uma maior subjetividade na medida em que é produzido, muitas vezes, por escritores de renome que escrevem num determinado jornal. A reportagem, por sua vez, tem um interesse maior em focalizar o acontecimento jornalístico, discuti-lo e analisá-lo, do

\footnotetext{
${ }^{8}$. “(...) la representación en él de brasileñas será seguramente mayor que el de todas las otras sociedades juntas (lo que no deja de ser un alivio para los pecadores irredentos como este escriba)." (Coluna "Piedra de Toque" do jornal El País de fevereiro de 1999 - grifo nosso)

9 . "Todo lo que he visto y oído en esta fulgurante semana carioca parece una ilustración animada (...)" (idem - grifo nosso)
} 
ponto de vista de uma pretensa objetividade jornalística, o que neutraliza a manifestação de marcas do sujeito da enunciação. Por outro lado, funciona como um recurso retórico no texto, uma vez que faz com que o leitor acredite que o enunciador tem um conhecimento maior daquilo que comenta, porque esteve presente ao acontecimento. Esse efeito persuasivo do discurso, então, pode ser reforçado na medida em que a manifestação do ponto de vista do enunciador sobre os fatos que comenta constrói-se a partir de uma relação passional com o acontecimento comentado. Para termos uma idéia de como essa dimensão passional se constrói no texto de Llosa é necessário examinarmos como se manifesta a argumentação em torno do tema do carnaval brasileiro.

O elemento central a partir do qual se constrói a argumentação do texto de Vargas Llosa reside no fato de que os enunciados nele concretizados voltam-se para a questão do carnaval no Brasil como uma forma de liberação do corpo, o que dá vazão à manifestação da sexualidade. O próprio título de sua crônica já instaura esse ponto de vista: "A ereção permanente". Enquanto o sentido do nome "ereção" remete diretamente ao da excitação sexual, o advérbio "permanente" reporta à intensidade dessa excitação durante o período em que duram as festividades do carnaval carioca.

Para delinear os sentidos da paixão nessa crônica é possível observar como esse aspecto está refletido na visão que o enunciador apresenta do carnaval e nos usos da linguagem que faz para expor seu ponto de vista. Inicialmente, o sujeito enunciador é destinatário de um fazer persuasivo instaurado pelo destinador, tio Lucho, que nele desperta um querer: conhecer de perto o carnaval carioca. Esse querer é eufórico e, na medida em que não se realiza, mantém o sujeito do querer em estado de tensão. Sua visão do carnaval, em decorrência do relato do destinador, é apaixonada:

\footnotetext{
"Desde muito criança, quando ouvia o tio Lucho descrever as magias e as contorções do Carnaval carioca, eu sonhava ver o espetáculo de perto e, se possível, por dentro, em carne e osso. Consegui. Embora sessenta e dois anos de idade, freqüentes dispepsias e uma hérnia lombar não sejam as condições ideais para dela desfrutar, a experiência é proveitosa, e afirmo que, se toda a humanidade vivesse isso, haveria menos guerras, preconceitos, racismo, feiúra e tristeza no mundo (...)."10 (p. 281)
}

10. "Desde que, muy niño, oí describir al tío Lucho las magias y disfuerzos del Carnaval de Rio, soñaba con verlo de cerca, y, en lo posible, de dentro, en carne y hueso. Lo he conseguido. Aunque 62 años de edad, frecuentes dispepsias y una hernia lumbar no sean las condiciones óptimas para disfrutar de ella, la experiencia es provechosa, y afirmo que si toda la humanidad la viviera, habría menos guerras, prejuicios, racismo, fealdad y tristeza en el mundo, (...)." (idem). 
De forma circular, o texto de Llosa termina remetendo-se a seu começo, qual seja, a retomada do discurso eufórico sobre o espetáculo do carnaval carioca: "Mas, enquanto o Carnaval carioca existir, para quem o viver ou dele se lembrar, ou até o imaginar, a vida será melhor que o lixo que é normalmente, uma vida que, por alguns dias - como jurava o tio Lucho -, toca os faustos do sonho e se mistura com as magias da ficção" $" 11$ (p. 287).

Por outro lado, porém, em continuidade ao trecho citado em destaque acima, com que inicia sua crônica, o turista-enunciador aponta, segundo sua visão particular, para o caráter disfórico do evento, contrapondo à alegria do carnaval brasileiro alguns problemas sociais enfrentados pelo país: “(...) mesmo com, provavelmente, mais fome, desigualdades, loucura e um incremento cataclístico da natalidade e da Aids."12 (p: 281).

A exaltação do carnaval brasileiro, realizada pelo enunciador, constrói-se a partir da constatação de que, nessa festa popular, o corpo, enquanto representação da sexualidade, é o elemento centralizador de todas as atividades. Para confirmar a veracidade de seu ponto de vista, o enunciador chama a atenção do enunciatário para o fato de que, no ano de 1999 (ano em que ele assistiu ao espetáculo do carnaval no Brasil), uma das escolas de samba que participa do desfile do carnaval carioca, a "Caprichosos de Pilares", tem como enredo a vida do cirurgião plástico brasileiro Ivo Pitanguy.

Essa valorização do corpo durante as festividades do carnaval é exaltada a ponto de o enunciador afirmar que o apelo à sensualidade desfaz a distinção entre o belo e o feio, pois todas as pessoas que desfilam nas escolas de samba, quer tenham um corpo lindíssimo quer não tenham, mostram-nos aos espectadores e, por meio da dança e da alegria que transmitem, tornam-se sempre belas; o feio desaparece, diluído na euforia da música, da dança, das cores, da luz, da fantasia, do calor. Os corpos nus ou semi-nus dos passistas, conforme afirma Llosa, recuperam as festas pagãs e desfazem a noção de pudor:

11. "Pero, mientras el Carnaval carioca exista, para quienes lo vivan o recuerden, o incluso imaginen, la vida será mejor de la basura que es normalmente, una vida que, por unos días - como juraba el tío Lucho - toca los fastos del sueño y se mezcla con las magias de la fícción." (idem)

12. “(...) aunque, sí, probablemente, más hambre, disparidades, locura, y un incremento cataclístico de la natalidad y el sida." (idem) 
“(...) poderia citar igualmente todos os demais órgãos e pedaços da anatomia humana que, no Carnaval carioca, com a condição de levar em cima uma prenda ínfima (a famosa tanga batizada de 'fio dental'), exibem-se com desembaraço, alegria e liberdade que eu acreditava desaparecidas desde que a moral cristã substituiu a pagã e pretendeu ocultar e proibir o corpo humano, em nome do pudor". (p. 282) ${ }^{13}$.

Em contraposição a essa euforia carnavalesca, o enunciador não deixa de citar as várias mortes que aconteceram durante os quatro dias de carnaval, fruto da violência social no país; os problemas econômicos que o Brasil enfrenta, o que justificou um empréstimo de quarenta milhões de dólares feito pelo FMI; as críticas de alguns intelectuais que consideram as festividades carnavalescas uma alienação; o constante aumento de gastos com a fabricação de fantasias e carros alegóricos para o período de carnaval, realizado pelos organizadores das diferentes escolas; o aumento de gastos públicos com as festas populares, especialmente num período de crise econômica não só nacional mas também internacional. Quando se pergunta, porém, se toda essa festa não seria então um desperdício, uma insensatez, uma loucura, responde dizendo que não, pois considera o carnaval brasileiro uma festa "no sentido mais antigo e primitivo da palavra: quando a sensatez e a razão eram ainda frutas exóticas, e homens e mulheres praticavam o potlach e eram ainda, essencialmente, emoção, sentidos à flor da pele, intuição, instinto."14 (p. 285)

Para reafirmar a visão do carnaval brasileiro como uma manifestação da festa primitiva, o texto de Llosa instaura uma relação intertextual com o de Bakhtin. O recurso de citação de um autor que não é conhecido pelo público comum, como é o caso do leitor do jornal El País no qual o texto de Llosa é primeiramente publicado, pode querer funcionar como um argumento de autoridade para referendar o ponto de vista do sujeito enunciador. Por outro lado, porém, esse é um recurso recorrente nas diferentes

13 . “(...) podría citar igualmente todos los demás órganos y pedazos de la anatomía humana, que, en el Carnaval de Rio, a condición de llevar encima una prenda pigmea (la famosa tanga bautizada hilo dental), se exhiben con un desenfado, alegría y libertad que creía desaparecidos desde que la moral cristiana reemplazó a la pagana y pretendió ocultar y prohibir el cuerpo humano, en nombre del pudor." (idem)

14 . “(...) en el sentido más antiguo y primitivo de la palabra: cuando la sensatez y la razón eran aún frutas exóticas, y hombres y mujeres practicaban el potlach y eran todavía, esencialmente, emoción, sentidos a flor de piel, intuición, instinto". (idem) 
crônicas reunidas em seu livro A linguagem da paixão e é responsável, ainda, por um certo distanciamento do enunciador em relação a seu leitor, quando pensamos no universo discursivo do leitor comum do jornal, o que pode refletir-se num elitismo e conservadorismo de seus comentários. Para examinarmos esse caso de seu procedimento argumentativo, vale a pena observar seu discurso no momento em que insere a referência a Mikhail Bakhtin.

\begin{abstract}
"Tudo o que vi e ouvi nessa fulgurante semana carioca parece uma ilustração animada de sua tese sobre a cultura popular que desenvolveu em seu deslumbrante livro sobre Rabelais. Sim, aqui está, saída das entranhas dos estratos mais humildes da escala social, essa resposta desavergonhada, irreverente, ferozmente sarcástica, aos padrões estabelecidos da moral e da beleza, essa negação vociferante das categorias sociais e das fronteiras que tendem a separar e hierarquizar as raças, as classes, os indivíduos, numa festa que tudo iguala e confunde, ao rico e ao pobre, ao branco e ao negro, ao empregado e o patrão, à madame e sua empregada, que fulmina temporalmente os preconceitos e as distâncias e estabelece, num parêntese de ilusão, num oásis com sexo e música a granel, aquele 'mundo ao contrário' do poema de José Agustín Goytisolo (...)" $)^{\prime 15}$ (p. 285-6).
\end{abstract}

Conforme se pode observar na citação acima, o enunciador do texto de Llosa traz o discurso de Bakhtin para o seu e transpõe a visão do autor russo sobre o carnaval na Idade Média para o carnaval carioca na Idade Contemporânea. Ele reforça, no caso carioca, a diluição das diferenças sociais para a qual Bakhtin havia apontado anteriormente. Assim, o carnaval do Rio de Janeiro, por meio da valorização do corpo, da sua manifestação sexual, desfaz, segundo o texto em análise, as diferenças de classe, o preconceito racial, o sexual e o moral. Seu discurso apaixonado, ao realizar essa comparação entre as duas realidades, pode ser captado, por exemplo, na frequiência com que os adjetivos aparecem no trecho de seu texto acima reproduzido: "fulgurante", "animada", “deslumbrante”, “desavergonhada”, “irreverente”, "sarcástica", "vociferante".

15. "Todo lo que he visto y oído en esta fulgurante semana carioca parece una ilustración animada de sus tesis sobre la cultura popular, que desarrolló en su deslumbrante libro sobre Rabelais. Sí, aquí está, salida de las entrañas de los estratos más humildes de la escala social, esa respuesta desvergonzada, irreverente, ferozmente sarcástica, a los patrones establecidos de la moral y la belleza, esa negación vociferante de las categorías sociales y de las fronteras que tienden a separar y jerarquizar a las razas, a las clases, a los individuos, en una fiesta que todo lo iguala y lo confunde, al rico y al pobre, al blanco y al negro, al empleado y al patrón, a la señora y su sirvienta, que fulmina temporalmente los prejuicios y las distancias, y establece, en un paréntesis de ilusión, en un espejismo con sexo y música a granel, aquel mundo al revés del poema de José Agustín Goytisolo (...)” (idem) 
Ao reconhecer, porém, a transformação do desfile do carnaval carioca numa atividade econômica voltada para o incremento do turismo no Rio de Janeiro, com a criação do "Sambódromo", que retira das ruas da capital carioca a manifestação espontânea que era o desfile de carnaval anteriormente, o enunciador do texto de Llosa remete seu leitor para as diferentes formas de manifestação popular "espontânea" das festas de carnaval ao contar que elas são comuns em todos os locais da cidade, desde os bairros mais populares até os de classe alta, e como se vê, certa noite, diante de um grupo de foliões nas ruas cariocas:

\begin{abstract}
"Na principal avenida da bem burguesa Ipanema, por exemplo, certa noite, dou de cara com um grupo de uns mil travestis, rapazes e homens maduros que, vestidos de mulher ou seminus, 'sambam' freneticamente atrás de um trio elétrico e se beijam, acariciam-se e pouco menos que fazem amor diante dos olhares divertidos, indiferentes ou entusiastas dos vizinhos, que, das janelas, brincam com eles, aplaudem-nos e lhes jogam confete e serpentinas." ${ }^{16}$ (p. 286)
\end{abstract}

Novamente a questão da quebra dos padrões morais é ressaltada e o carnaval considerado o espaço que propicia essa realidade. Na seqüência do trecho acima citado, o enunciador de Llosa irá reafirmar essa idéia ao dizer que "o protagonista da festa [de carnaval] é o corpo humano"17 e, imediatamente em seguida, descreverá um amanhecer carioca em que muitos dos sentidos, mas principalmente o olfato, remetem às mais diferentes formas de manifestação da sexualidade, percebidas pelo que ele chama de “espesso aroma seminal"18 espalhado pelas ruas da cidade.

Sua constatação final a respeito da festa carnavalesca é a de que ela inibe qualquer manifestação popular que possa desencadear uma "revolução social" e que nenhum plano social conseguirá "controlar a libido dessa sociedade de demografia galopante que chega já aos 170 milhões de cidadãos"19 (p. 287). Novamente o discurso

16. "En la principal avenida de la muy burguesa Ipanema, por ejemplo, me doy de bruces una noche con una comparsa de un millar o millar y medio de travestidos, muchachos y hombres maduros que, vestidos de mujer o semidesnudos, 'samban' frenéticamente detrás de un camión con una orquesta, y se besan, acarician y poco menos que hacen el amor ante las miradas divertidas, indiferentes o entusiastas de los vecinos, que, desde las ventanas, cambian bromas con ellos, los aplauden y les lanzan mistura y serpentinas." (idem)

17. "El protagonista de la fiesta es el cuerpo humano" (idem)

18 . “(...) espeso aroma seminal (...)” (idem)

19. “(...) controlar la libido de esa sociedad de demografia galopante que raspa ya los 170 millones de ciudadanos." (idem) 
manifestado pelo enunciador do texto de Llosa pretende julgar a sociedade brasileira pela perspectiva das festas de carnaval. Primeiramente procura reafirmar a imagem da "indolência" do brasileiro que é, muitas vezes, veiculada no exterior, o que reforça a concepção do povo colonizado e que não tem capacidade de se tornar uma sociedade séria. Em segundo lugar, e em conseqüência da anterior, pretende confirmar o erotismo do carnaval carioca com a cifra demográfica do país, sugerindo serem essas festividades, por causa da liberação sexual que julga acontecer nesse período, responsáveis pelo crescimento da população, o que vem a ser outro clichê por meio do qual muitos estrangeiros vêem o Brasil.

Ainda no último parágrafo do texto de Llosa podemos detectar uma referência ao então presidente do Brasil, Fernando Henrique Cardoso, quando continua sua caracterização do comportamento da população brasileira. Essa referência aparece de forma diferente na tradução do texto em português e no texto em espanhol, tal como foi publicado no jornal El País, em fevereiro de 1999. Na versão original há uma crítica depreciativa do presidente ao considerá-lo um "presidente de luxo", expressão que é eliminada na tradução brasileira ${ }^{20}$.

Embora nas últimas linhas do texto o enunciador volte a valorizar euforicamente o carnaval carioca, ao dizer que para quem o viveu ou o imagina a vida será sempre melhor, os sentidos que o discurso veiculado pelo texto de Llosa reafirmam é o da fantasia carnavalesca. A paixão manifestada nos inúmeros adjetivos que aparecem no texto, nas descrições extasiadas da exposição corporal dos carnavalescos e nos comentários analíticos do enunciador é o suporte do discurso que se pretende livre e capaz de dizer aquilo que quer. Nesse sentido, então, sua subjetividade pode ser captada não só por meio das marcas lingüísticas deixadas no texto, mas também por sua manifestação ideológica. O discurso do enunciador do texto insere-se numa formação discursiva própria daquele que está de fora do que vê, pois se coloca numa realidade social superior àquela que examina.

\footnotetext{
${ }^{20}$. Na versão em espanhol do referido jornal o trecho é assim redigido: "Y sudará sangre, sudor y lágrimas esse presidente de lujo que es Fernando Henrique Cardoso para imponer la austeridad y la disciplina económica al pueblo que lo eligió.”. Na tradução brasileira da editora Arx o mesmo trecho é redigido da seguinte forma: "E suará sangue, suor e lágrimas o presidente Fernando Henrique Cardoso para impor a austeridade e a disciplina econômica ao povo que o elegeu." (p. 287).
} 


\section{Conclusão.}

A paixão, enquanto procedimento de construção do discurso, pode manifestar-se de diferentes formas. $\mathrm{O}$ que procuramos mostrar por meio da análise de dois discursos tipologicamente distintos, um literário e outro jornalístico, foi a maneira como cada um deles explora o aspecto passional para se constituir enquanto texto e para captar seu leitor. Além disso, inserimos essa exploração da dimensão passional do discurso para caracterizarmos alguns elementos do contexto cultural brasileiro em dois momentos históricos diferentes: final do século XIX e final do século XX.

No caso do texto literário, pudemos perceber que a paixão é o que move uma narrativa que é contada de um sujeito a outro em segundo plano. A técnica do narrador consiste em diluir sua presença para dar voz a duas personagens que conversam. Uma delas, o conselheiro, conta a seu amigo o que se passou em determinada época de sua vida, constituindo-se, assim, num narrador de segunda instância. Sua história, ao mesmo tempo em que trata da paixão amorosa, é narrada de forma apaixonada e escutada por um interlocutor também modalizado pela paixão, que interfere assim no processo narrativo. Na medida em que esse enunciador e esse enunciatário internos ao discurso do conto são a projeção de um sujeito da enunciação em primeira instância, pode-se dizer que o discurso deste último, embora apagado, é também apaixonado. O conto de Machado de Assis simula a situação de uma peça de teatro em que as personagens falam aquilo que é discursivizado por um sujeito enunciador que só pode ser captado por intermédio da fala da personagem, pois é o seu autor. O leitor é um espectador que assiste ao drama e nele se envolve, tal como o amigo do conselheiro, metaforicamente refletindo esse leitor, também o faz.

No caso do texto da crônica jornalística, a dimensão passional pode ser percebida como a maneira a partir da qual o enunciador se relaciona com o tema do discurso que produz, ao mesmo tempo que se transforma em um procedimento argumentativo que visa despertar no leitor a mesma paixão, modalizando-o pelo querer. As marcas de subjetividade presentes no discurso de Llosa são também uma forma de aproximação de seu leitor, o que corrobora o princípio passional de sua construção. O que se pode pensar como outra possibilidade de exame é como captar a paixão num outro tipo de texto não literário em que as marcas de subjetividade estivessem mais apagadas. 
Quanto ao aspecto da representação cultural, o que se pode constatar por meio do exame dos dois textos analisados é que eles apresentam visões diferentes do imaginário da cultura brasileira. Enquanto o de Machado de Assis constrói um cenário em que a relação entre sujeito e objeto reflete uma tensão entre um querer e um poder que delimitam e conformam o desejo, o de Llosa descreve um cenário em que o desejo não tem limites, é distenso, e em que o querer e o poder não se opõem, pois a relação verdadeira é a da complementaridade. Não se pode deixar de notar, porém, que o próprio texto machadiano aponta para um relaxamento do comportamento de suas personagens em relação ao objeto da paixão quando mostra que o elemento desencadeador da trama passional é uma aposta, isto é, um jogo que se estabelece entre dois actantes da narrativa. Como constatamos na análise, a transformação do estado relaxado para o tenso na trama amorosa do conto machadiano se dá em função do apagamento do valor econômico do objeto do desejo, isto é, os dois amigos que fizeram a aposta deixam de caracterizar Quintília como uma mulher rica e passam a valorizar seu aspecto sensível.

Por meio do exame de duas diferentes formas de manifestação da paixão nos dois textos analisados, procurou-se demonstrar ainda como eles articulam certas características do imaginário da cultura brasileira. Ao mesmo tempo em que a sociedade brasileira constitui-se internamente por um olhar sobre suas próprias ações, o olhar externo concretizado no texto de Llosa caracteriza esse sujeito social como libertino, miscigenado, o que, do ponto de vista da manifestação do ser é uma característica positiva, mas do ponto de vista do fazer é negativa. Conforme mostramos no texto de Llosa, sua perspectiva é a de que a não contenção desse comportamento eróticopassional da sociedade brasileira leva-a a um estado de dominação. Na medida em que o povo brasileiro é caracterizado pela forte manifestação passional, tem sua imagem ligada à do homem primitivo, à do silvícola que é subjugado pelo colonizador, mais racional e mais preocupado com seus interesses políticos e econômicos. É nesse sentido que apontamos aqui a crítica de Llosa ao estado de dominação a que ele entende estar submetida a sociedade brasileira. 
CASA Vol. 2.n.2, dezembro de 2004

\section{REFERÊNCIAS BIBLIOGRÁFICAS.}

BERTRAND, Denis. Précis de sémiotique littéraire. Paris : Nathan, 2000.

CORTINA \& MARCHEZAN. Teoria semiótica: a questão do sentido. In: MUSSALIM \& BENTES (Org.). Introdução à lingüística: fundamentos epistemológicos, vol. 3. São Paulo: Cortez, 2004. (p. 393-438)

FERREIRA, Aurélio Buarque de Holanda. Novo Aurélio século XXI: o dicionário da língua portuguesa. 3. ed. revista e ampliada. Rio de Janeiro: Nova Fronteira, 1999.

FONTANILLE, Jacques. Le désespoir. Documents. Paris: Groupe de recherches sémiolinguistiques, 2(6), 1980.

Les espaces subjectifs. Introduction à la sémiotique de l'observateur. Paris : Hachette, 1989, pp. 11-48).

__. Sémiotique du discours. Limoges : Presses Universitaires de Limoges, 1998.

_. Sémiotique et littérature. Essais de méthode. Paris: Presses Universitaires de France, 1999.

GREIMAS, Algirdas Julien. Semântica estrutural. Trad. de Haquira Osakabe. São Paulo: Cultrix, 1976.

De la colère. Étude de sémantique lexicale. Documents. Paris: Groupe de recherches sémio-linguistiques, 3(27), 1981.

_. De l'imperfection. Périgueux: Pierre Fanlac, 1987.

GREIMAS, Algirdas Julien \& FONTANILLE, Jacques. Semiótica das paixões. Dos estados de coisas aos estados de alma. Tradução de Maria José R. Coracini. São Paulo: Ática, 1993.

LLOSA, Mario Vargas. La erección permanente. In: Diario El País. Piedra de Toque. Madrid, 1999 (http://www.geocities.com/boomlatino/p1999.html)

A linguagem da paixão. Trad. de Wladir Dupont. São Paulo: Arx; 2002.

MACHADO DE ASSIS, Joaquim Maria. A desejada das gentes. In:Obra completa. vol. II. Rio de Janeiro : Nova Aguilar, 1997, p. 504-11.

MARSCIANI, F. Les parcours passionnels de l'indifférence. Documents. Paris : Groupe de recherches sémio-linguistiques, 6(53), 1984.

OLIVEIRA, A. C. \& LANDOWSKI, E. (eds.). Do inteligível ao sensível. Em torno da obra de Algirdas Julien Greimas. São Paulo: EDUC, 1995. 